\title{
Sylwia Słowińska (red.), Inicjatywy kulturalne angażujące osoby 50+ jako przestrzeń indywidualnego rozwoju i kształtowania kapitału społecznego, Wydawnictwo Uniwersytetu Zielonogórskiego, Zielona Góra 2015, ss. 239
}

Kapitał społeczny od kilku lat cieszy się ogromnym zainteresowaniem badaczy wielu dziedzin nauki. Owo zainteresowanie wyrosło przede wszystkim z konsekwencji, jakie przyniosła rewolucja przemysłowa, techniczna i informacyjna. Nie tylko ekonomiści, ale także przedstawiciele nauk przyrodniczych, humanistycznych i społecznych coraz częściej odwołują się w swoich badaniach do kapitału społecznego rozumianego jako „wytwór życia społecznego" (Malewski 2001, s. 210), w którym istotne stają się zdrowe relacje społeczne, dbanie o dobro wspólne i wszelkie działania oparte na zasadzie współpracy (Czapiński 2011, s. 292). Tak ujęty kapitał społeczny wyrósł z potrzeby zhumanizowania nurtu kapitału ludzkiego, który - w ujęciu ekonomicznym - zależał od jakości kompetencji poszczególnych obywateli i był przeliczany na wynik ekonomiczny. W ujęciu społecznym zaś nadał społeczeństwu nowe znaczenie - świadome i aktywne uczestnictwo każdego obywatela w kreowaniu przestrzeni publicznej i społecznej za pomocą dostępnych mechanizmów kulturowych: tradycji, religii i historii.

$\mathrm{Z}$ tym jednak wiąże się wiele zobowiązań nałożonych na samych obywateli, a mianowicie rozwijaniem kompetencji interpersonalnych, umiejętności rozumienia sieci symbolicznych i rzeczowych powiązań, umiejętności identyfikowania kodów kulturowych, którym towarzyszy m.in. zdolność łączenia się w grupy czy gotowość do działania na rzecz innych oraz zaufanie.

W perspektywie możliwości, jakie dało Polsce choćby wejście w struktury Unii Europejskiej - wspólnoty o zróżnicowanych doświadczeniach kulturowych, politycznych i ekonomicznych - uzyskanie odpowiedzi m.in. na takie pytania jak: czy Polacy są gotowi do budowania społeczeństwa obywatelskiego? które grupy społeczne są najbardziej predysponowane, gotowe na wyzwanie, jakim jest budowanie społeczeństwa obywatelskiego? jakie 
czynniki i mechanizmy sprzyjają rozwojowi kapitału społecznego? - wydaje się oczywiste. Jednak tak nie jest. Wynika to przede wszystkim z niskiej aktywności Polaków na rzecz tworzenia społeczeństwa obywatelskiego i braku wykształconych trwałych postaw prospołecznych ${ }^{1}$.

Jedną z form aktywności, która wyzwala i kształtuje postawy sprzyjające budowaniu społeczeństwa obywatelskiego, jest aktywność kulturalna, której wiele miejsca poświęciła redaktor naukowa książki pt. Inicjatywy kulturalne angażujace osoby 50+ jako przestrzeń indywidualnego rozwoju i ksztattowania kapitału społecznego Sylwia Słowińska. Warto zaznaczyć, że recenzowana książka jest rozszerzoną wersją raportu z badań przeprowadzonych przez zespół badaczy z Wydziału Pedagogiki, Socjologii i Nauk o Zdrowiu Uniwersytetu Zielonogórskiego w ramach projektu Inicjatywy z udziałem osób 50+ a rozwój kapitału społecznego w województwie lubuskim - diagnoza i ewaluacja².

Praca została podzielona na trzy części. Pierwsza z nich wprowadza do teoretycznych i metodologicznych założeń badań inicjatyw kulturalnych angażujących osoby $50+^{3}$.

Pierwszy rozdział tej części, opracowany przez Edytę Mianowską, Ewę Narkiewicz-Niedbalec, Katarzynę Walentynowicz-Moryl, wprowadza do rozważań wokół kapitału społecznego. Autorki rozdziału dokonują teoretycznej analizy trzech kategorii kapitału: ludzkiego, społecznego i konsumenckiego, słusznie przy tym zauważając, że pojęcie jest pojemne zarówno w odniesieniu do relacji społecznych, jak i uwarunkowań wpływających na dobro wspólne (s. 17). Odwołując się nie tylko do najbardziej znanych teorii kapitału społecznego ${ }^{4}$, jak teoria Colemana, Putnama, Bourdieu czy Fu-

1 Badania pokazują, że 18\% Polek i Polaków angażuje się w działania na rzecz organizacji i grup społecznych. Warto dodać, że aktywność społeczna ma najczęściej charakter filantropijny i polega na przekazaniu $1 \%$ podatku lub zbiórce finansowej na rzecz potrzebujących. Problematyka została szeroko omówiona w raporcie Piotra Adamiaka pt. Zaangażowanie społeczne Polek i Polaków. Wolontariat, filantropia, 1\% i wizerunek organizacji pozarzadowych. W perspektywie ostatnich badań Eurobarometru z 2015 roku, które wskazują, że aktywność społeczną najchętniej podejmują mieszkańcy Irlandii (42\%), Danii (39\%) i Holandii (38\%), wskaźnik aktywności społecznej Polaków jest niski.

2 Projekt został zrealizowany w ramach programu Ministra Kultury i Dziedzictwa Narodowego pn. „Obserwatorium kultury”.

3 Rozwiązywanie problemów i odpowiadanie na potrzeby osób starszych są jednymi z najważniejszych priorytetów zapisanych w strategicznych dokumentach krajowych i regionalnych, np. w „Strategii rozwoju kraju 2020”, czy programach rządowych, np. w „Rządowym programie na rzecz aktywności społecznej osób starszych na lata 2014-2020”.

${ }_{4}$ Na uwagę zasługuje pozycja Thomasa Piketty, który w książce pt. Kapitał XXI wieku zmienia sposób myślenia m.in. na temat kapitału społecznego i społeczeństwa obywatel- 
kuyamy, autorki dostrzegły, że „brak jednoznacznego stanowiska badaczy w kwestii rozumienia kapitału społecznego przekłada się na różnorodność przyjmowanych arbitralnie sposobów pomiaru i problemy w interpretowaniu oraz porównywaniu wyników różnych badań, co w konsekwencji osłabia samą kategorię kapitału społecznego" (s. 18).

Z perspektywy przyjętych przez zespół badaczy Uniwersytetu Zielonogórskiego założeń istotne stało się rozumienie kapitału społecznego jako „sieci społeczne regulowane normami moralnymi lub zwyczajem [...], które wiążą jednostkę ze społeczeństwem w sposób umożliwiający jej współdziałanie z innymi dla dobra wspólnego" (s. 55). Ważne w tym miejscu okazały się następujące pytania: czy i w jakim zakresie aktywność kulturalna/ /uczestnictwo w kulturze ma szansę przyczyniać się do budowania sieci powiązań oraz zaufania między ludźmi, umożliwiając im współdziałanie na rzecz dobra wspólnego? Co pozwala uznać animację kultury za użyteczną metodę kształtowania aktywności kulturalnej sprzyjającej rozwijaniu kapitału społecznego? (s. 49). Z tymi pytaniami próbowała zmierzyć się Sylwia Słowińska w rozdziale zatytułowanym Aktywność kulturalna osób 50+ jako przestrzeń rozwijania kapitału społecznego - konteksty teoretyczne. W poszukiwaniu odpowiedzi na nie cenna wydała się krytyczna ocena kapitału społecznego, który - jak podkreśla autorka - początkowo był postrzegany w sposób pozytywny jako zasób społecznie pożyteczny, odgrywający istotną rolę wzmacniającą procesy rozwoju w wymiarze ekonomicznym i społecznym (s. 31). Aktualnie badacze podchodzą do tej kategorii dość krytycznie, nie zawsze bowiem kapitał społeczny wiąże się z korzyściami społecznymi, a nawet może powodować dodatkowe koszty i problemy, ale też służyć niepożądanym interesom oraz krępować swobodny rozwój i aktywność jednostek. Dlatego autorka zwraca uwagę na pojęcie kapitału pomostowego - zgodnie z podejściem Barbary Lewenstein i Marii Theiss - „opartego na więziach słabszych, zrzeszeniowych, łączących ludzi o heterogenicznych cechach demograficznych i społeczno-ekonomicznych, reprezentujących rozmaite poglądy i wyznających różne wartości, który przynosi pożytek nie tylko członkom grupy, ale także szerszej społeczności”. Funkcję tego rodzaju kapitału mogą pełnić np. organizacje pozarządowe (s. 32).

Dodatkowo ważne dla autorki w poszukiwaniach badawczych było rozumienie aktywności kulturalnej jako uświadomionej części szeroko pojmo-

skiego. Różnorodność ujęć kapitału społecznego i uwarunkowań jego wzmacniania odnajdziemy w redagowanej przez Krystynę Marzec-Holkę pozycji pt. Kapitał społeczny a nierówności. Kumulacja i redystrybycja, 
wanego uczestnictwa w kulturze (s. 39). Powyższe założenia pozwoliły na sformułowanie kilku ważnych wniosków. Animacja zawiera potencjał stymulowania rozwoju kapitału społecznego, ponieważ pozwala na współdecydowanie i współtworzenie przez poszczególnych członków społeczności5. Docenia rolę więzi międzyludzkich, wagę przynależności do grupy i wspólnoty, odwołując się przy tym do kultury społeczności i kultury lokalnej. Animacja wzmacnia także więzi ze środowiskiem lokalnym i zaangażowanie na rzecz środowiska. Widoczne jest to szczególnie w inicjowaniu przez jednostki samodzielnych działań, opartych na współpracy i komunikacji, pozwalających na samorealizację i przeciwstawianie się obojętności. Animacja zakłada, że w ludziach tkwi potencjał, który za pośrednictwem liderów społecznych należy wyzwolić, i za pomocą którego można rozwiązywać indywidualne problemy i angażować się w zmiany społeczne.

Trzeci rozdział tej części, Założenia metodologiczne i opis procedury badawczej, został opracowany przez Edytę Mianowską, Ewę Narkiewicz-Niedbalec, Małgorzatę Olejarz, Katarzynę Walentynowicz-Moryl oraz Sylwię Słowińską. Na uwagę zasługuje fakt, że objęta badaniem grupa, tj. osoby po 50 roku życia, została ujęta nie w perspektywie deficytów i zagrożeń, ale potencjału, niezbędnego do budowania społeczeństwa obywatelskiego. Celem badań prowadzonych przez zielonogórski zespół było rozpoznanie możliwości oddziaływań inicjatyw kulturalnych aktywizujących osoby powyżej 50 roku życia oraz określenie poziomu ich kapitału społecznego. W toku przeprowadzonych badań udało się ustalić, że wśród wskaźników sprzyjających budowaniu kapitału społecznego ważną rolę odgrywa: zaufanie do innych uczestników, poczucie emocjonalnej bliskości z innymi uczestnikami oferty, poczucie wsparcia ze strony innych uczestników oferty i ekwiwalentność relacji (s. 55). Istotne dla podejmowania działań na rzecz dobra wspólnego jest przenoszenie idei wspólnych działań poza aktywność, którą wyznacza oferta kulturalna, ale także działanie uczestników na rzecz innych, powstawanie nowych pomysłów, ukierunkowanych na ich aktywizację oraz samopomoc.

Drugą część książki pt. Inicjatywy kulturalne angażujące osoby 50+ opracowały Mianowska, Narkiewicz-Niedbalec, Walentynowicz-Moryl. Celem autorek była diagnoza inicjatyw kulturalnych (ofert aktywności kulturalnej) angażujących osoby 50+. Warto zauważyć, że najwięcej takich inicjatyw podejmują domy kultury, stowarzyszenia i biblioteki, wspierane ofertami uniwersytetów trzeciego wieku. Wartościowa z punktu widzenia przepro-

${ }^{5}$ Szerzej o animacji i upowszechnianiu kultury pisze m.in. Józef Kargul w podręczniku akademickim pt. Upowszechnianie. Animacja. Komercjalizacja kultury. 
wadzonej przez autorki diagnozy była próba stworzenia mapy podmiotów angażujących osoby starsze na terenie województwa lubuskiego. To, co wydaje się istotne $\mathrm{z}$ perspektywy budowania społeczeństwa lokalnego, to fakt, że inicjatorami działań kulturalnych są najczęściej członkowie organizacji społecznych. Inicjatywy przyjmują charakter stały lub okazjonalny i prezentują różnorodne dziedziny kultury (m.in. muzykę, literaturę, sport, taniec).

Drugi rozdział tej części poświęcono ewaluacji oferty zajęć angażujących osoby 50+. Cenna wydaje się pozytywna ocena działań organizacji pozarządowych ukierunkowanych na potrzeby osób 50+, której wyznacznikiem jest adekwatność i różnorodność oferty, jej dostępność oraz satysfakcja i zadowolenie z uczestnictwa w zajęciach (s. 92).

Znaczenie inicjatyw kulturalnych (ofert aktywności kulturalnej) angażujqcych osoby 50+ dla rozwoju kapitału społecznego to trzeci rozdział tej części, który został poświęcony analizie badań w zakresie poziomu zaangażowania uczestników w ofertę instytucji kultury i organizacji. Wyniki badań pozwalają postrzegać lubuszan jako społeczność o wysokim poziomie kapitału społecznego (w perspektywie doświadczeń Polaków). Towarzyszy temu także wysoki poziom zaufania do władz lokalnych, urzędników administracji publicznej i mediów, co sprzyja poczuciu samostanowienia. Świadomość wymiernych korzyści z uczestnictwa w wolontariacie na rzecz społeczności osiedlowych i lokalnych zwiększa poziom kapitału społecznego mieszkańców województwa lubuskiego.

Czwarty rozdział tej części, opracowany przez Małgorzatę Olejarz, Bogdana Idzikowskiego i Marka Zadłużnego, pt. Uczestnictwo osób 50+ w różnych formach zajęć $w$ kontekście budowania kapitału społecznego, to analiza różnorodnych form aktywności osób po 50 roku życia. Podobnie jak w innych regionach Polski, ogromnym zainteresowaniem wśród badanych cieszą się zespoły artystyczne, a uczestnictwo w nich sprzyja nawiązywaniu, podtrzymywaniu i wzmacnianiu społecznych więzi. Dla podtrzymania pozytywnych efektów uczestnictwa w różnorodnych formach aktywności kulturalnej (bo także w sekcjach, klubach), ale też inicjowania działań na rzecz wspólnego dobra, niezbędne jest intencjonalne wsparcie ze strony organizacji pozarządowych, instytucji kultury, a przede wszystkim liderów społecznych, w tym animatorów kultury i andragogów (s. 192).

Piąty rozdział pt. Rola realizatorów zajęć a rozwój kapitału społecznego uczestników - perspektywa realizatorów został opracowany przez Sylwię Słowińską. To, na co autorka zwraca szczególną uwagę, to fakt, że rola inicjatorów działań animacyjnych w budowaniu kapitału społecznego nie jest intencjonalna, cele inicjatyw mają zaś charakter partykularny a nie prospołeczny. 
Dlatego nie możemy mówić tu o budowaniu kapitału pomostowego, ale raczej kapitału wiążącego. Ważne jest zatem, aby uczestnicy mieli większą swobodę w podejmowaniu autonomicznych decyzji dotyczących różnorodnych form aktywności społecznych. Najsilniej bowiem kooperują ci członkowie społeczności, którzy poprzez realizację celów grupy mogą realizować cele ukierunkowane na wspólne dobro.

Ostatnia część recenzowanej książki, Aktywność kulturalna osób 50+pomiędzy indywidualnym rozwojem a prospołecznością, jest podsumowaniem zaprezentowanych wyników badań, opracowanym przez Słowińską i Furmanka. Na uwagę zasługuje kilka wniosków, które z perspektywy poruszanej problematyki warto przytoczyć. Energia życiowa uczestników, otwartość, chęć działania, spotykania się z ludźmi, to doskonała podstawa to przedsięwzięć animacyjnych inicjujących działania prospołeczne angażujące ludzi w różnym wieku. Inicjatywy kulturalne mogą być przestrzenią zrzeszania się wokół wspólnych wartości i celów, dając szansę na realizację nie tylko indywidualnych potrzeb, ale na organizowanie społeczności lokalnych. Warto przy tym pamiętać, że tego rodzaju działaniom powinno towarzyszyć celowe wzmacnianie kooperacyjności i ukierunkowanie energii uczestników na cele prospołeczne. Sprzyjające zaś jest „różnicowanie oferty i stopniowe poszerzanie repertuaru działań, czyli realizowanie modelu aktywności kulturalnej łączącej indywidualne cele samorealizacyjne i prospołeczne" (s. 230).

Recenzowana książka ma wiele walorów poznawczych i praktycznych. Te ostatnie są mi najbliższe, ostanie lata bowiem pozwoliły mi zaangażować się w wiele inicjatyw o charakterze oddolnym, których efekty - podobnie jak badacze z Uniwersytetu Zielonogórskiego - dostrzegam w zmianie świadomości członków społeczności lokalnych w zakresie wspólnego dobra, wzroście ich aktywności na rzecz poprawy życia w perspektywie indywidualnej i grupowej, różnorodnych ofertach kulturalnych, edukacyjnych, społecznych, realizowanych przez instytucje publiczne, organizacje pozarządowe, lokalne grupy działania czy grupy samopomocowe (w tym grupy wsparcia).

Oczywiście, aby mówić o wysokim poziomie kapitału społecznego polskich społeczności lokalnych, musi upłynąć jeszcze wiele czasu. Ten jednak - korzystając $z$ doświadczeń autorów zaprezentowanych w recenzowanej książce - warto poświęcić m.in. na edukowanie nie tylko samych członków społeczności, ale przede wszystkim liderów, animatorów społecznych i menedżerów kultury, budowanie realnych sieci wsparcia przez przedstawicieli administracji publicznej, placówek edukacyjnych, opiekuńczo-wychowawczych, instytucji pomocy społecznej, aktywizacji społecznej 
i zawodowej, przedsiębiorców i przede wszystkim przedstawicieli władz samorządowych.

Inicjatywy kulturalne angażujące osoby 50+ jako przestrzeń indywidualnego rozwoju i kształtowania kapitału społecznego to pozycja obowiązkowa dla tych, których codzienna praktyka zawodowa ukierunkowana jest na inicjowanie i koordynowanie działań na rzecz środowisk lokalnych, wzmacniania ich kapitału społecznego i budowania społeczeństwa obywatelskiego.

Katarzyna Kuziak

\section{Bibliografia}

Adamiak P. (2014), Zaangażowanie społeczne Polek i Polaków. Wolontariat, filantropia, $1 \%$ i wizerunek organizacji pozarzadowych, Warszawa.

Czapiński J. (2011), Kapitał społeczny, w: Czapiński J., Panek T. (red.), Diagnoza społeczna 2011. Warunki i jakość życia Polaków, Warszawa.

Kargul J. (2012), Upowszechnianie animacji. Komercjalizacja kultury, Warszawa.

Malewski M., Edukacja dorosłych w pojęciowym zgiełku. Próba rekonstrukcji zmieniajacej się racjonalności andragogiki, „Teraźniejszość - Człowiek - Edukacja” 2001, nr 2.

Marzec-Holka K. (red.) (2009), Kapitał społeczny a nierówności. Kumulacja i redystrybycja, Bydgoszcz.

Piketty T. (2015), Kapitał w XXI wieku, Warszawa. 